\title{
Hydrocarbon Spill Site Characterization by Electrical Resistivity Tomography and Ground Penetrating Radar Methods - a Review
}

\author{
Oki Austin Oyinkuro ${ }^{1^{*}}$ and Kigighe Alvan Wariebi ${ }^{2}$ \\ ${ }^{1}$ Department of Geology, Niger Delta University, Amassoma, Bayelsa State, Nigeria. \\ ${ }^{2}$ Department of Science Lab. Technology/Physics, Federal Polythecnic, Ekowe, Bayelsa State,
} Nigeria.

\section{Authors' contributions}

This work was carried out in collaboration between both authors. Author OAO designed the study, performed the statistical analysis, wrote the protocol and wrote the first draft of the manuscript. Author KAW managed the analyses of the study and the literature searches. Both authors read and approved the final manuscript.

Article Information

DOI: $10.9734 / A J E E / 2017 / 36742$ Editor(s):

(1) Angelo Paone, Biologia, Scienze della Terra, Istituto Tognazzi, Italy.

(1) Bello Yusuf Idi, Federal University Dutse, Nigeria (2) Cyril Nwankwo, University of Port Harcourt Choba, Nigeria. Complete Peer review History: http://www.sciencedomain.org/review-history/21396

Mini-review Article

Received $13^{\text {th }}$ September 2017 Accepted $3^{\text {rd }}$ October 2017 Published $13^{\text {th }}$ October 2017

\begin{abstract}
Assessment of the source and geometry of contaminated soils by hydrocarbon spills is the first step towards designing an effective remediation programme. Electrical Resistivity Tomorgraphy and Ground Penetrating Radar are shown in this review to easily delineate spills under certain conditions. On a 2D-geoelctric profile of the subsurface, recent hydrocarbons spills are reflected as highly resistive anomalous zones, as biodegradation occurs spills become more conductive and may be masked by conductive soil. On a radargram fresh hydrocarbon spills are observed in zones of saturation where resistive fresh hydrocarbon spills displaces conductive water in pore spaces creating anomalous zones. Accurate interpretation of geoelectric profiles and radargrams in the Niger Delta requires knowledge of the lithology of the site of contamination which could easily be obtained by shallow drilling or pitting.
\end{abstract}


Keywords: Electrical resistivity tomography; ground penetrating radar; hydrocarbon spills; soil contamination.

\section{INTRODUCTION}

The Niger Delta is the largest wetland in Africa and also the third largest in the world. For decades oil exploited from the Niger Delta has been the major source of foreign exchange for Nigeria, which has been amongst the top ten oil producing nations in the world. Statistics in public domain show that over the last three decades, more than 400,000 metric tonnes of crude oil has been spilled into the creeks and soils of the Niger Delta, some $70 \%$ of which are yet to be recovered [1]. The National Oil Spill Detection and Response Agency (NOSDRA) declared it had located 1,150 oil spill sites abandoned by various oil companies within the Niger Delta [2]. These spills which are largely due to aging facilities, operator errors and sabotage have massively devastated the biodiversity, air, land, surface and underground water bodies of the Niger Delta, whose local inhabitants are mainly farmers and fishermen.

Geophysical methods offer a relatively fast, noninvasive, cost effective and efficient process for characterizing hydrocarbon contaminant plumes in the subsurface. These methods employed independently or integrated with other geophysical or non-geophysical methods have been used successfully to determine the source and geometry of plumes which served as a basis for efficient remediation procedure designs $[3,4,5,6]$.

This research $\mathrm{x}$-rays the principles and methodology of Electrical Resistivity Tomography and Ground Penetrating Radar methods. It highlights their application in hydrocarbon spill detection and mapping with some likely expected results and drawbacks of these methods in mapping and monitoring soil contamination in areas devastated by spills in the Niger Delta.

\section{PHYSIOGRAPHY AND GEOLOGY OF THE STUDY AREA}

The Niger Delta is a complex prolific basin formed by an extensional rift system in the Niger Delta and Gulf of Guinea, on a passive continental margin near the west coast of Nigeria between latitudes $3^{\circ} \mathrm{N}$ and $6^{\circ} \mathrm{N}$ and longitudes $5^{\circ} \mathrm{E}$ and $8^{\circ} \mathrm{E}$ [7]. It is one of the largest sub areal basins in Africa with an expanse of about 75,000 $\mathrm{km}$, a total area of 300,000 square kilometers, sediment fill of up to 500,000 cubic $\mathrm{km}$ and a sediment fill of $9-12 \mathrm{~km}$ [8]. The Niger Delta is bound on the northwest by a subsurface continuation of the Benin flank, on the east by the Calabar flank and to the south by the Oban Masif [9]. The major lithostratigraphic units observed on a well section through the Niger Delta consist of an upper delta top facies, a middle delta front lithofacies and a lower prodelta lithofacies [7]. The lithostratigraphic units correspond respectively with the uppermost Benin Formation aged Oligocene to recent, the Agbada Formation which lies beneath the Benin Formation aged Eocene to recent and the lowest lying Akata Formation aged Paleocene to recent [10]. The Akata Formation is composed mainly of marine shales with sandy and silty beds which are believed to have been laid down as turbidites and continental slope fills with an estimated thickness of $7,000 \mathrm{~m}$. The Agbada Formation which the the petroleum bearing unit in the Niger Delta, consists mostly of shoreface and channel sands with minor shales in the upper parts and an intercalation of sands and shales in equal proportion in the lower parts, with a thickness of over 3,700 $\mathrm{m}$ [11]. The Benin Formation consisting of continental sands and gravels is about $280 \mathrm{~m}$ thick and may be up to $2,100 \mathrm{~m}$ in the region of maximum subsidence [12].

\section{MATERIALS AND METHODS}

\subsection{Electrical Resistivity Tomography}

This method involves introducing electrical current into the subsoil with the aid of a Terrameter through current electrodes and measuring the resistance of the earth material to the flow of electricity by potential electrodes. Data is acquired repeatedly along profile lines to give a 2D image of the subsurface (Fig. 2) which shows the lateral and vertical variation of the earth's electrical resistance, a method commonly referred to as Electrical Resistivity Profiling, Imaging or Tomography.

The lateral extent using this method is dependent on the electrode array spread, whereas, depth of investigation increases by an increase in electrode spacing for a constant array spread. Investigations could extend to a few hundreds of meters before resolution becomes compromised. Electrode array configurations employed depends largely on the interest of the survey. 


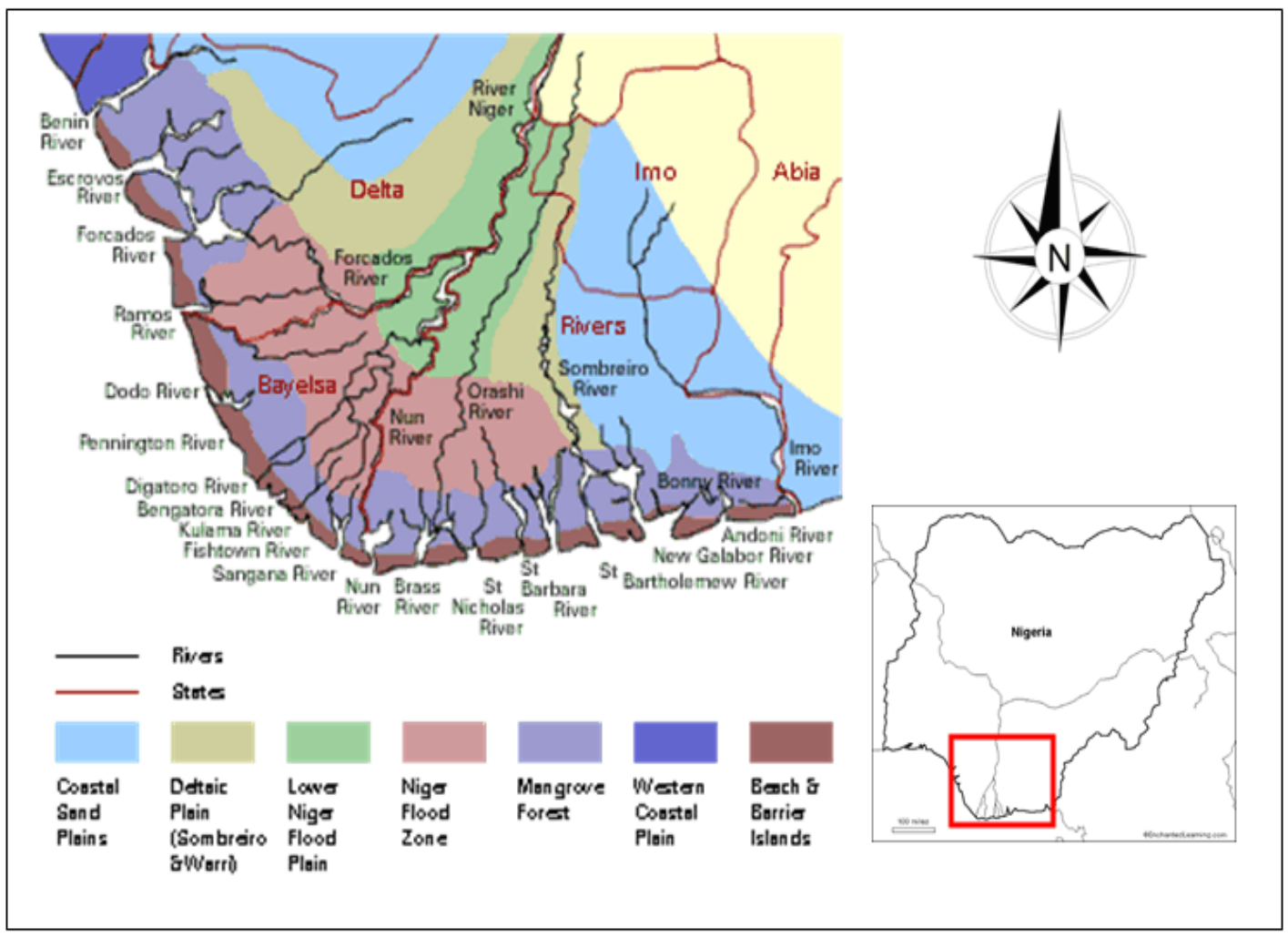

Fig. 1. Map of the Niger Delta

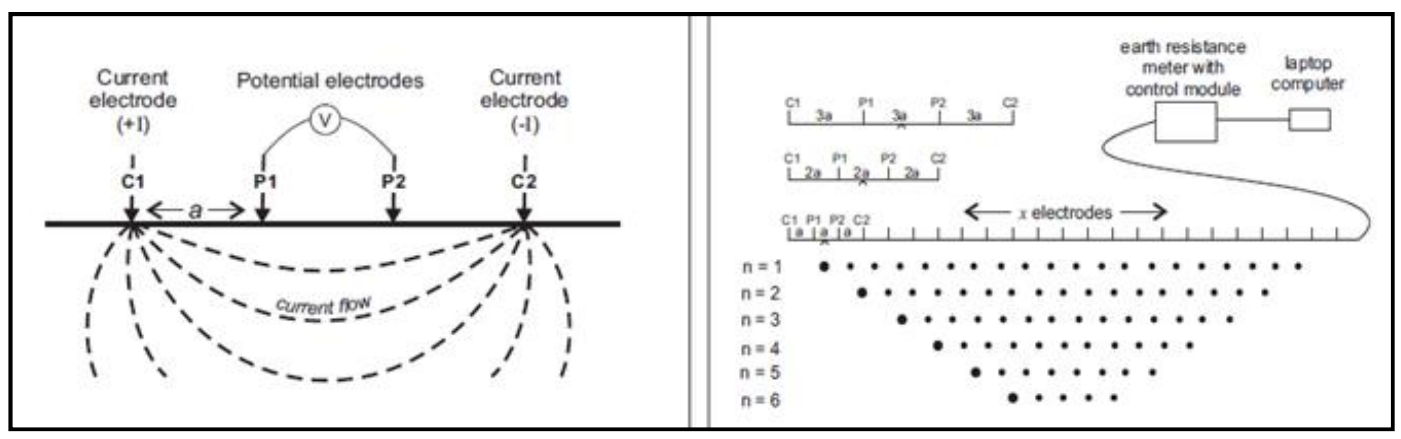

Fig. 2. Basic electrical profiling configuration

Wenner array is the most common array, it is usually employed where there is an equal interest in vertical and lateral resolution; in cases where lateral resolution is of greater interest dipole-dipole arrays have been employed $[13,14]$. In acquiring 2D apparent resistivity data, the lateral coverage must be reasonably greater than the expected width of the target of interest, there must also be a detectable variation in the electrical resistance of the target from the surrounding country rock. Data acquired is then fed into a resistivity inversion software to produce
2D geo-electric profiles of the surveyed area. Gridded 2D investigation at regular intervals can be used to generate 3D profiles across the area of interest. For more details of Electrical Resistivity method see $[15,14]$.

The theoretical basis for the application of geoelectrical method for hydrocarbon spill detection and mapping in the subsurface is dependent on the contrasting electrical properties of hydrocarbons, soil and groundwater $[16,17]$. The magnitude of the contrast depends mainly on the 
hydrocarbon contaminant age and some environmental processes [3,18,4]. Early research established that recent hydrocarbon spills are associated with high resistivity anomalies, whereas, mature spills showed reduced resistivity anomalies [19,20]. In mature hydrocarbon contamination sites increased conductivity was as a result of increased Total Dissolved Solids in pore water in the soil. Other physical, chemical and biological factors like soil type, microbial activity, organic matter, cation exchange and water table depth compounded to cause increased conductivity observed [3,18,4]. As such, during resistivity profile interpretation environmental factors as well as age of spills must be taken into account to forestall misleading conclusions [21,22,23]. Some results of 2D and 3D survey profiles across spill sites in the Niger Delta showed agreement with early literature. Results of two Electrical Resistivity Imaging profiles across a zone of recurrent hydrocarbon spills in Oshika community of Ahoada in Rivers state [6] showed fresh spills characterized by high resistivity response in the subsoil (Fig. 3).

Using Electrical Resistivity Tomography to investigate the impact of recent hydrocarbon spills on a shallow aquifer system in Sapele town of Delta state [21] also showed results with high resistivity values at subsurface spill accumulation points (Fig. 4). [22] showed low resistivity associated with mature spills (Fig. 5) which was in line with early literature, while investigating mature spills along hydrocarbon pipeline routes in Yenagoa. 3D depth slices of Electrical Resistivity Images on an hydrocarbon contaminated site with fresh spill over matured spill at Forcados in Delta state [24] showed freshly contaminated sites had higher resistivity than much older spills (Fig. 6). Older spill had a higher resistivity response than saline background subsoil. A major drawback of this method would be observed when sampling mature spills in the commonly saline clay rich subsoil in the Niger Delta. It becomes dicey in determining the source of observed low resistivity values.

\subsection{Ground Penetrating Radar}

The GPR method involves a technique of imaging the subsurface at high frequencies, it makes use of a radio wave transmitter to transmit electromagnetic waves at frequencies between $50 \mathrm{MHz}$ and $2.5 \mathrm{GHz}$ in short pulses of less than 20 ns into the subsurface structure [25]. When transmitted waves are incident on an interface of significant dielectric permittivity contrast, some of the energy is scattered, refracted or reflected back to the surface where it is detected by a receiver (Fig. 7). Variation in the reflected arrivals on the receiver is a factor of the number of interfaces with dielectric contrast the transmitted wave encountered. The principles involved are similar to seismic, except GPR employs

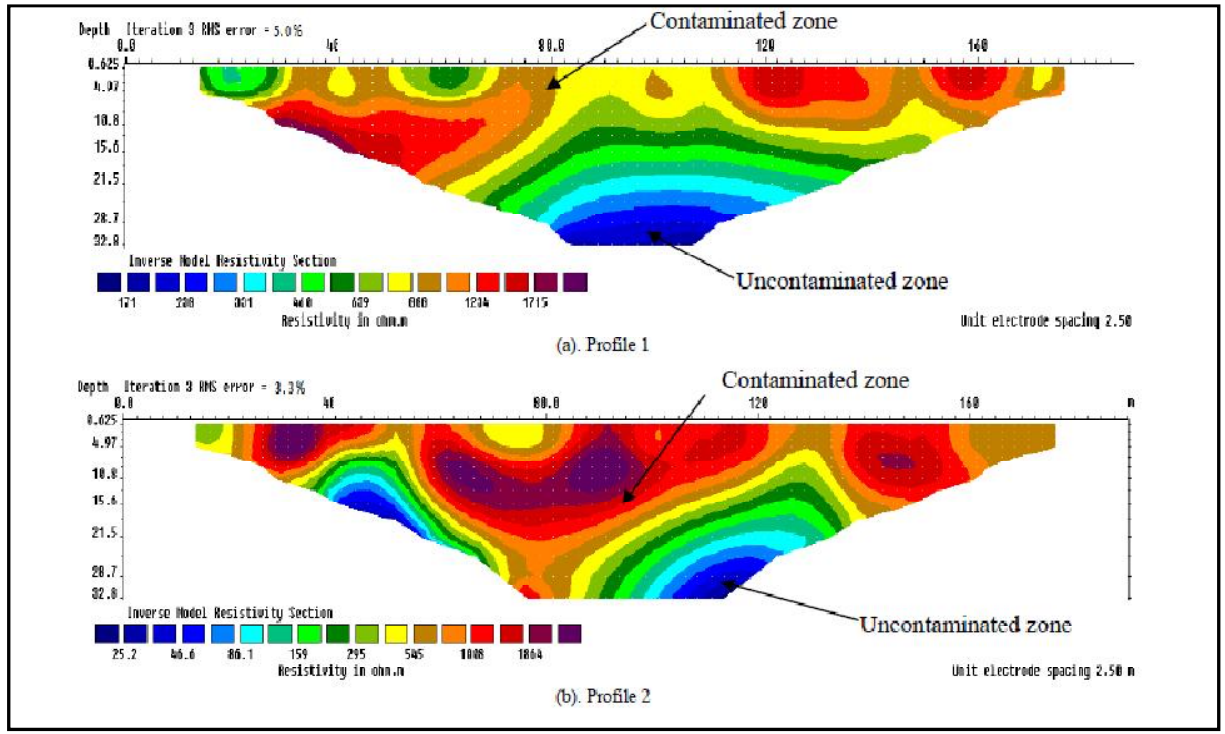

Fig. 3. 2D geoelectric profile across recent hydrocarbon contaminated site in Ahoada (Nwankwo and Emujakporue, [6]) 


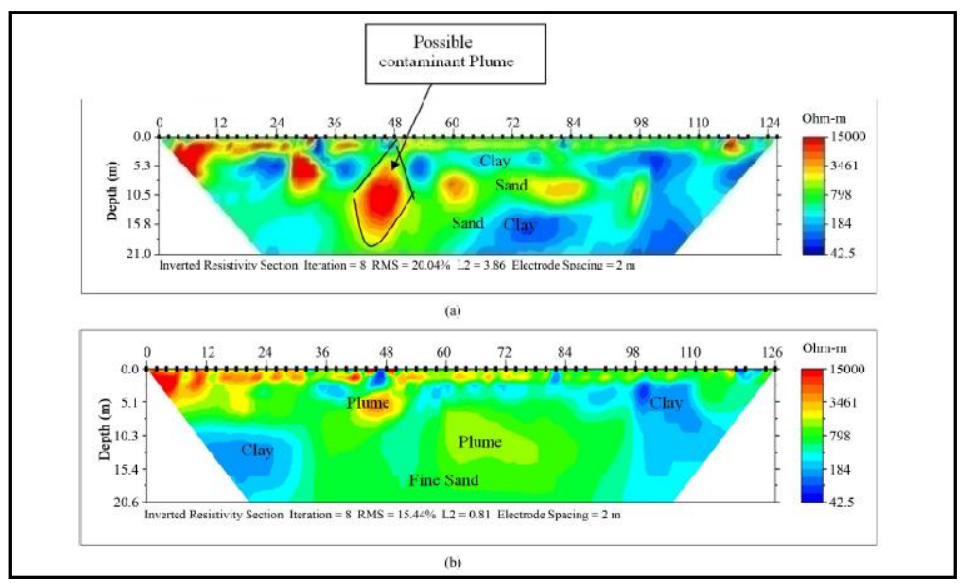

Fig. 4. 2D geoelectric profile across recent hydrocarbon contaminated site (Uchegbulam and Ayolabi [21])

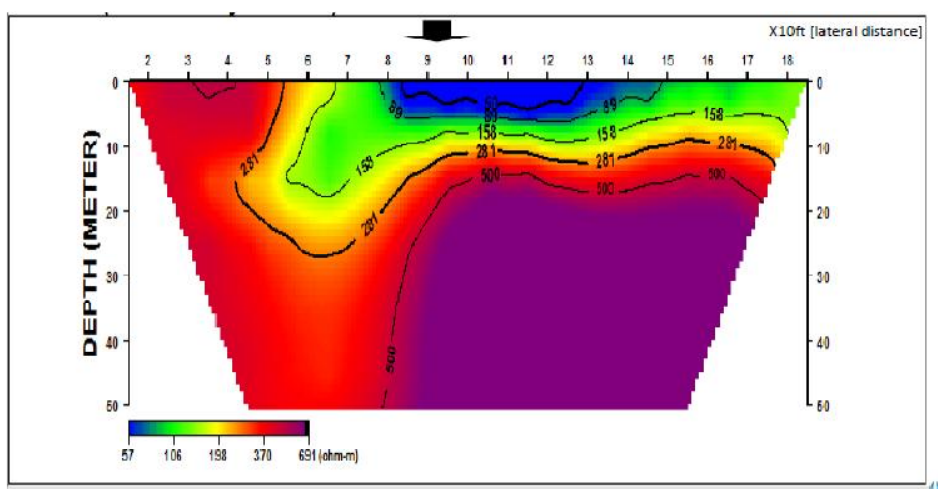

Fig. 5. 2D geoelectric profile across mature hydrocarbon contaminated site (Oki et al. [22])

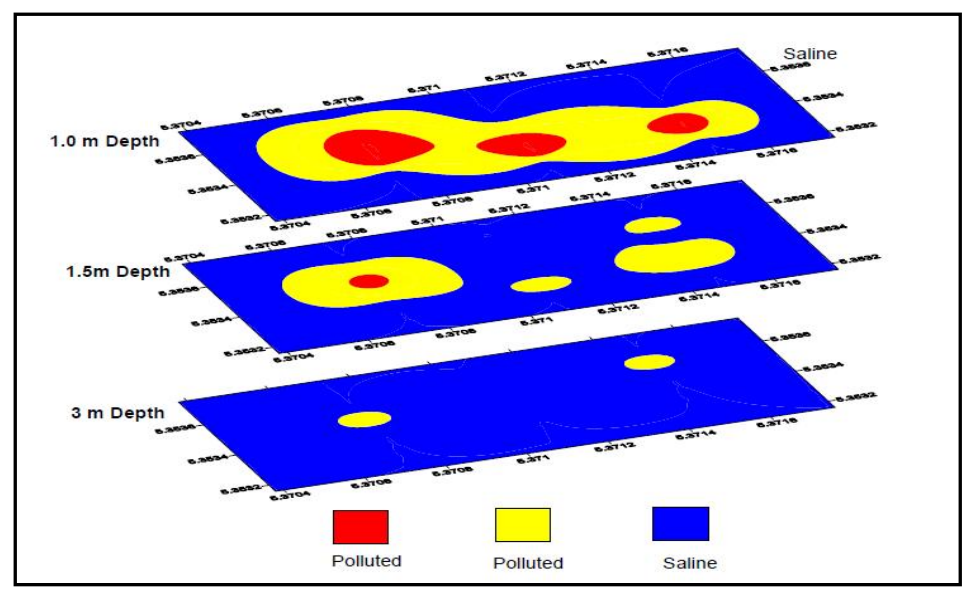

Fig. 6. 3D depth slices of a geoelectric profile across recent hydrocarbon contaminated site at Forcados (Atakpo and Akpoborie, [24])

electromagnetic energy rather than acoustic energy, also, reflection at interfaces is due to electrical properties variation as against mechanical properties in seismic. Transmitted 
signals with low frequency have a greater depth penetration but produce low resolution received signals. The radar frequency employed for a given survey is thus chosen to provide an acceptable trade-off between penetration and resolution [5]. The receiver measures the variation in strength of reflected signals with time to produce 1-D representation of the subsurface beneath the antennas called a Radar Scan.

To build a 2-D profile of the subsurface referred to as a Radargram, the antenna is traversed across the surface of interest to obtain a number of adjacent scans. Stacking of adjacent Radargrams generates 3-D Radargram cubes from which depth slices of interest can be extracted.

Surface GPR surveys generate high vertical resolved images of boundaries between horizontal layers, where there is a distinct variation in water content of these layers. In the unsaturated zone this depends solely on water retention capacity of the subsurface material, the water table is usually a clear boundary in a sandy aquifer system [26].

Some drawbacks of the GPR method are depth limitation and requirement of an even ground surface for data collection. Depth limitation is primarily caused by attenuation of radar signals by clay rich soil, saline groundwater and blocky subsurface materials like landfill, cobbles and rebars, as such, GPR works very well in low loss material like sands and gravel and performs poorly in highly conductive materials like clays For more details of how the method works see $[27,28]$.
The GPR has been shown to have a potential in certain field conditions for delineating the geometry of hydrocarbons in the subsoil $[29,30]$. This potential exist when the electrical properties of such contaminants vary from water. For instance, when hydrocarbons and air are present in the pore spaces of dry quartz sand there is no significant contrast in the relative permittivities of these materials $\left(\varepsilon_{\mathrm{r}}\right.$ Air $=1, \varepsilon_{\mathrm{r}}$ Dry Hydrocarbons $=3$ to $5, \varepsilon_{\mathrm{r}}$ Dry quartz $=5$ ), as such, detection becomes challenging. However, in a case where hydrocarbons exists with water $\left(\varepsilon_{\mathrm{r}}\right.$ Water $\left.=81\right)$, a significant and detectable contrast exists in areas where hydrocarbon displaces water relative to areas where no water has been displaced. Air, hydrocarbon and dry quartz are relatively high velocity media for propagating radar energy when compared to water and clays. A detectable decrease in radar wave attenuation should suffice in areas where fresh hydrocarbons displace water [31]. This concept changes in cases of mature hydrocarbon spills, which available early literature showed increased in conductivity with time, as such, becomes a low velocity medium with time $[3,18,4]$.

In a 2-D GPR study of fresh hydrocarbon contaminated soils south-west of Kuala Lumpur in Malaysia [5] results showed three distinct reflection patterns (Fig. 8) representing a top sandy layer with flat high amplitude reflections, an oil contaminated middle zone characterized by discontinuous chaotic reflections where fresh hydrocarbons displaced water in pore spaces and a thick underlying soft clay zone where radar waves were highly attenuated due to high conductivity of clays, usually referred to as a free reflection zone were identified.

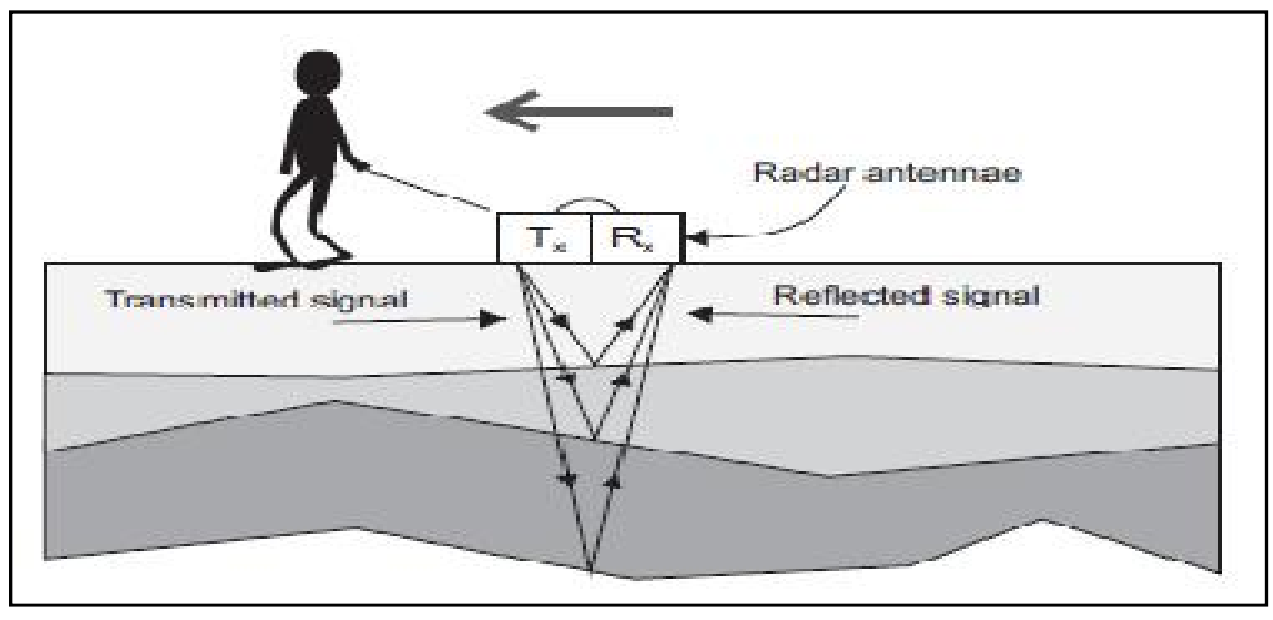

Fig. 7. Schematic of GPR data collection system 


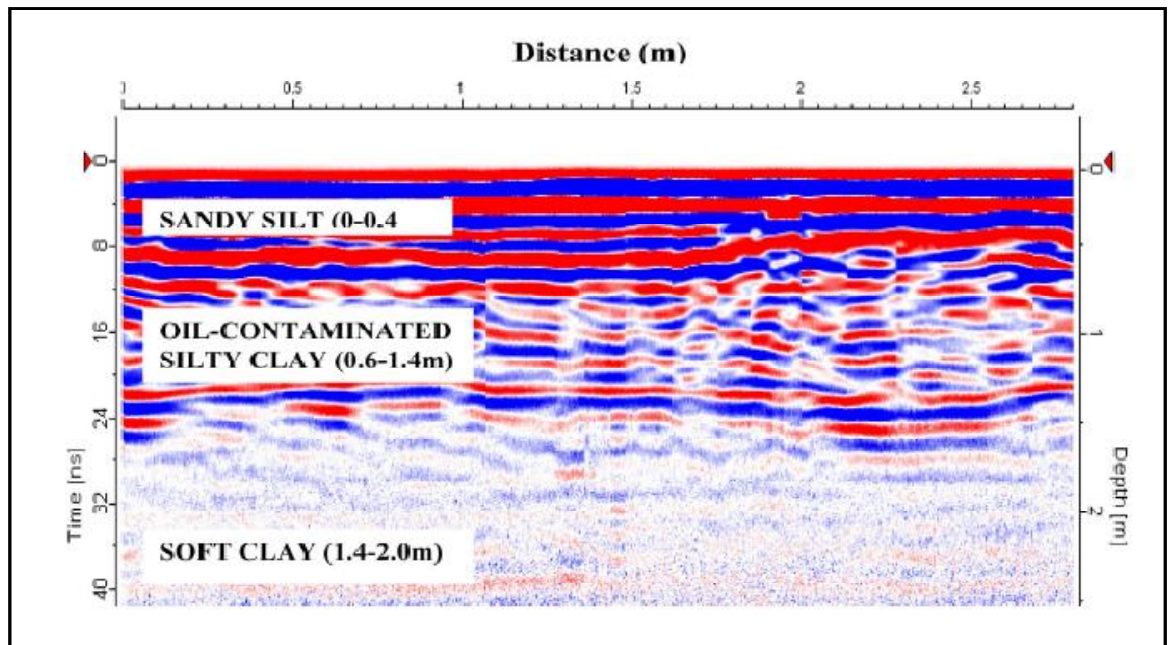

Fig. 8. Radargram of hydrocarbon contaminated soil in Kuala Lumpur (Hamza et al. [5])

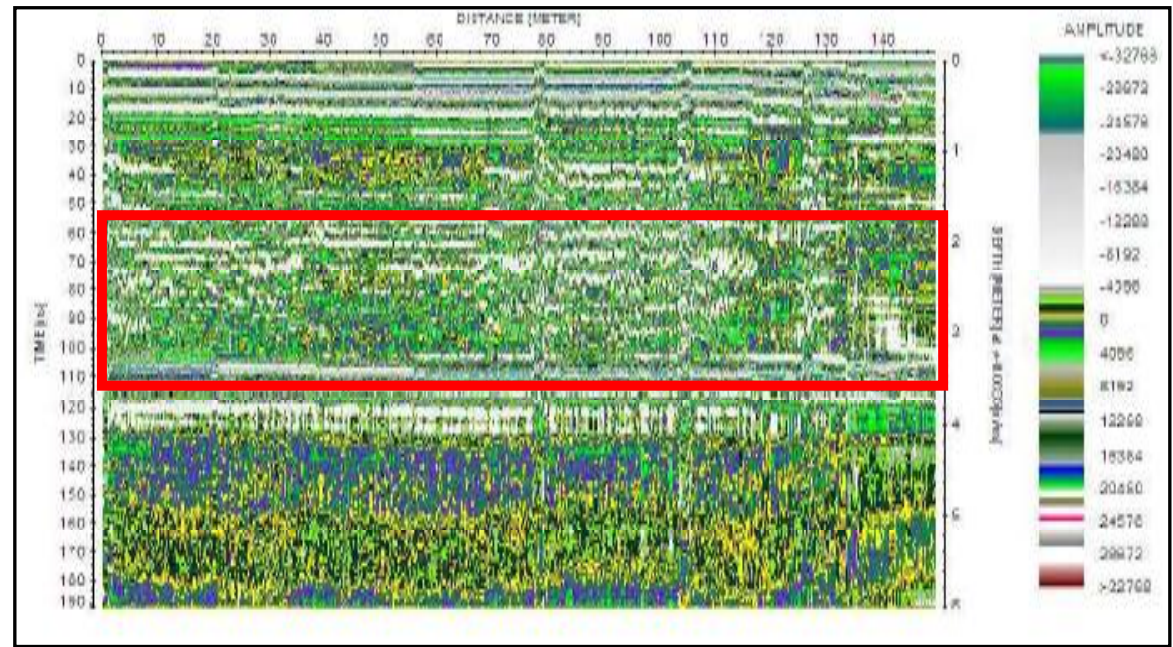

Fig. 9. Radargram of hydrocarbon plumes in soil at lbeno L. G. A (Udotong et al. [32])

Radargram from a survey mapping mature hydrocarbon plumes in Ibeno, L. G. A. of Akwa Ibom State, Niger Delta of Nigeria [32] presented horizontally stratified near surface high amplitude events, indicative of sand units. Below the first zone depths of $1 \mathrm{~m}$ to $3 \mathrm{~m}$ are attenuated reflection events, attenuation of radar waves here was due to high conductivity of mature hydrocarbon plumes. Beyond the second zone from depths of $3 \mathrm{~m}$ to $4 \mathrm{~m}$, high amplitude horizons indicative of sand units occur (Fig. 9 above).

\section{CONCLUSION}

This review has shown the effectiveness of noninvasive geophysical methods for the characterization of hydrocarbon spills in the soil, it also highlights some important factors and drawbacks of both the Electrical Resistivity Tomography and Ground Penetrating Radar methods. Most parts of the Niger Delta have a characteristic thin clayey or sandy top soil, the sub-soil is mostly an intercalation of sand and clays and this layer is underlain by sandstones which is usually the shallow or first aquifer in a multi-aquifer hydrogeologic system.

Most areas of the deltaic environment have shown pockets of saline water intrusion especially along the coast. While acquiring Electrical Resistivity Tomography and Ground Penetrating Radar data in the Niger Delta, it is 
important to carry out rough plots in the field to ascertain anomalous zones. Pitting with a Handauger on anomalous and non-anomalous zones (as control) across the survey profile must then be done to corroborate information of the local lithology and establish its impact or non effect on the acquired data, this would greatly aid in drawing informed conclusions.

Electrical Resistivity Tomography and Ground Penetrating Radar data have been shown in this review to work best on fresh hydrocarbon spills, owning to the increasing conductivity of spills with age. Mature spills are easily masked by conductive clayey soils and saline environment, as such, for efficient results to be obtained, remediation designs and data acquisition must be carried out as soon as the spill occurs.

\section{COMPETING INTERESTS}

Authors have declared that no competing interests exist.

\section{REFERENCES}

1. UNDP. Niger Delta Human Development Report; 2006.

Available:http://www.ng.undp.org/

(Accessed 5 August, 2017)

2. Newspaper this Day Article. NOSDRA detects 1,150 oil spill sites; 2008.

3. Sauck WA. A conceptual model for the geoelectrical response of LNAPL plumes in granular sediments. Proceedings of Symposium on the Application of Geophysics to Engineering and Environmental Problems, March 22-26, 1998, Chicago, Illinois, USA. 1998;805817.

4. Atekwana EA, Sauck WA, Werkema Jr. DD. Investigations of geoelectrical signatures at a hydrocarbon contaminated site. Journal of Applied Geophysics. 2000;44:167-180.

5. Hamzah U, Ismail MA, Samsudin AR. Geophysical techniques in the study of hydrocarbon-contaminated soil. Bulletin of the Geological Society of Malaysia. 2008; 54:133-138.

6. Nwankwo CN, Emujakporue GO. Geophysical method of investigating groundwater and sub-soil contamination-a case study. American Journal of Environmental Engineering. 2012;2(3):4953.
7. Reijers TJA, Petters SW, Nwajide CS. The Niger Delta Basin, in: Reijers TJA (ed), selected chapters on geology: SPDC corporate reprographic services, Warri, Nigeria. 1996;103-144.

8. Fatoke OA. Sequence stratigraphy of the Pliocene-Pleistocene Strata and Shelf Margin Deltas of the Eastern Niger Delta, Nigeria (PhD Thesis): University of Houston, Texas, U SA; 2010.

9. Murat RC. Stratigraphy and palaeogeography of the cretaceous and Lower Tertiary in Southern Nigeria: In African Geology, Dessauvagie, T. J. F and Whiteman, A. J (ed) Ibadan University Press. 1972;251-266.

10. Short KC, Stauble AJ. Outline of geology of Niger Delta: American Association of Petroleum Geologist Bulletin. 1967; 51(5):764-772.

11. Doust H, Omatsola E. Niger Delta: In Edwards JD, Santogrossi (ed) Divergent/ Passive Margin Basins: American Association of Petroleum Geologists memoir. 1990;48:201-236.

12. Whiteman A. Nigeria: Its Petroleum Geology, Resources and Potential. Graham and Trotman L.T.D. 1982;1:114131.

13. Yi MJ, Kim JH, Song Y, Cho SJ, Chung $\mathrm{SH}$, Suh JH.Three-dimensional imaging of subsurface structures using resistivity data. Geophysical Prospect. 2001;49(4): 483-497.

14. Loke $\mathrm{MH}$. Electrical imaging surveys for environmental and engineering studies-a practical guide to 2D and 3D survey, Penang, Malaysia, Universiti Sains Malaysia; 1997. (Unpublished Short Training Course Lecture Notes).

15. Loke $\mathrm{MH}$, Baker RD. Practical techniques for 3D resistivity surveys and data inversion. Geophysical Prospecting. 1996b;44:499-523.

16. McNeill JD. Use of Electromagnetic methods for groundwater studies; in Ward, S. H (ed). Geotechnical and Environmental Geophysics (1): Society of Exploration Geophysics. 1990;191-218.

17. Benson AK, Fredrickson C, Mustoe NB. Ground Penetrating Radar, Electrical Resistivity, Soil and Water Quality studies integrated to determine source(s) and geometry of hydrocarbon contamination at a site in North-Central Arizona. Proceedings of $27^{\text {th }}$ Symposium on 
Engineering Geology and Geotechnical Engineering. 1991;38:1-13.

18. Sauck WA. A model for the resistivity structure of LNAPL plumes and their environs in sandy sediments. Journal of Applied Geophysics. 2000;44:151-165.

19. Mazac O, Benes L, Landa I, Maskova A. Determination of the extent of oil contamination in groundwater by Electrical methods. Geotechnical and Environmental Geophysics. 1990;2:107-112.

20. Olhoeft GR. Geophysical detection of hydrocarbon and organic chemical contamination. Proceedings of the Symposium on the application of Geophysics to Engineering and Environmental Problems, Oakbrook, Illinois, USA. 1992;587-595.

21. Uchegbulam $O$, Ayolabi EA. Application of electrical resistivity imaging in investigating groundwater pollution in Sapele Area, Nigeria. Journal of Water Resources and Protection. 2014;6:1369-1379.

22. Oki OA, Oborie E, Akana TS, Didie I. Assessment of hydrocarbon contamination in the soil along pipeline routes in Yenagoa, Southern Nigeria by the integration of Electrical Resistivity and Geochemical methods. Science and Industrial Technology Education Journal. 2015;3(1):110-132.

23. Ehirim CN, Adizua OF, Okorie PC. Geotechnical characterization of matured petroleum hydrocarbons impacted soil in Port Harcourt, Nigeria. Asian Journal of Earth Science. 2016;9(1):9-15.

24. Atakpo EA, Akpoborie Al. Electrical resistivity imaging of spilled crude at Obuguru inter-tidal flat, Forcados area, Delta State, Nigeria. Archives of Physics Research. 2011;2(4):166-175.

25. Davis JL, Annan AP. Ground-penetrating radar for high-resolution mapping of soil and rock stratigraphy. Geophysical Prospecting. 1989;37:531-551.

26. Ghinda T, Wehrer M, French H, Godio A, Pedersen L, Bastani M, et al. Evaluation of invasive and non-invasive techniques for monitoring of remediation processes and performance. European Commission Seventh Framework Programme Report D5 - 3. 2013;16-19.

27. Keary P, Brooks M, Hill I. An Introduction to Geophysical Exploration. $3^{\text {rd }}$ Edition Blackwell Scientific Publications. 2003; 225-228.

28. Reynolds JM. An introduction to applied and environmental geophysics. Wiley, Chichester. 1997;682-745.

29. Olhoeft GR. Direct detection of Hydrocarbons and Organic Chemicals with Ground Penetrating Radar and Complex Resistivity. In Proceedings of NWWA/API Conference on Petroleum Hydrocarbons and Organic Chemicals in GroundwaterPrevention, Detection and Restoration. Dublin, Ohio, USA. 1986;284-305.

30. Daniels JJ, Roberts RL, Vendi MA. Ground penetrating radar for the detection of liquid contaminants. Journal of Applied Geophysics. 1995;32:195-207.

31. Kim C, Daniels JJ, Guy ED, Radzevicius SJ, Holt J. Residual hydrocarbons in a water saturated medium: A detection strategy using ground penetrating radar. Environmental Geosciences. 2000;7(4): 169-176.

32. Udotong IR, Udotong JIR, Ofonime UMJ. Delineation of oil polluted sites in Ibeno $\mathrm{L}$. G. A, Nigeria using Geophysical Techniques. International Journal of Environmental, Chemical, Ecological, Geological and Geophysical Engineering. 2015;9(6):639-645.

(c) 2017 Oyinkuro and Wariebi; This is an Open Access article distributed under the terms of the Creative Commons Attribution License (http://creativecommons.org/licenses/by/4.0), which permits unrestricted use, distribution, and reproduction in any medium, provided the original work is properly cited.

Peer-review history:

The peer review history for this paper can be accessed here: http://sciencedomain.org/review-history/21396 